\title{
Governing the Outer Islands: Decentralisation in Kiribati and Tuvalu
}

\author{
Commonwealth Journal of Local Governance \\ Issue 2: January 2009
}

http://epress.lib.uts.edu.au/ojs/index.php/cjlg

\section{Phil Richardson}

United Nations Development Programme, Fiji

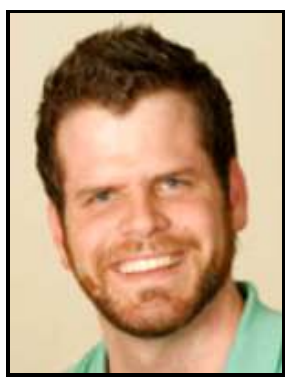

\section{Introduction}

For over a decade the governments of Kiribati and Tuvalu have adopted decentralisation policies to strengthen the role of local-level authorities in development. This can be seen as a response to both domestic policy drivers and global trends. However, while Kiribati and Tuvalu share a common past and many of the same development issues, the decentralisation process has taken distinct paths in the two countries. This paper takes stock of the Kiribati and Tuvalu experience, drawing on research, country-specific project evaluations and practitioner perspectives. It focuses on local governance at the outer island level and examines three dimensions of the decentralisation process: policy drivers; central-local relations; and integration of traditional and modern institutions of governance. ${ }^{1}$

\section{Drivers of decentralisation policy}

Similar factors have driven decentralisation policy in Kiribati and Tuvalu. This is unsurprising, given that the countries share common histories and developmental challenges. Until independence in 1971, the two island groups were part of one British protectorate, the Gilbert and Ellice Islands. By 1979, they had split to become two nations. Since then, Kiribati and Tuvalu have faced similar constraints

\footnotetext{
${ }^{1}$ Hassall and Tipu have recently published a valuable stock take of local government across the region, including Kiribati and Tuvalu, focussing mainly on institutional characteristics (Hassall and Tipu 2008).
} 
to development, such as limited natural resources, low economic growth, widely dispersed geography and vulnerability to the impacts of climate change. Migration from the outer islands to urban centres has also increased sharply since the 1990s, driven by the lure of the cash economy (Asian Development Bank 2003; 2007). These factors have made effective outer island governance extremely difficult. However, while the confluence of these concerns continues to threaten the future of outer island communities, there remains an enduring attachment to the island lifestyle, which has proved a powerful policy driver. This author noted the fondness with which residents of urban areas describe life on the islands, especially the plenteousness of traditional foods and persistence of cultural norms of sharing and reciprocity. It is thus apparent that the desire to maintain a way of life under threat, as much as any economic consideration, has shaped decentralisation. As the current Tuvalu national development plan laments: "the outer islands have always been regarded as the heart of the nation, however in the last decade the heart has become weaker" (Government of Tuvalu 2004).

The prioritization of local governance and local development has also had a political dimension, given that the majority of members of national parliaments in both Kiribati and Tuvalu come from outer island constituencies. This is despite the fact that half the population is now concentrated on the respective capital islands, Tarawa and Funafuti. It is in this context that the three aims of outer island development, the reversal of urbanization, and development of the capacity of local authorities, have been a prominent part of national development plans (Government of Kiribati 2003; Government of Tuvalu 2004), and perhaps partly explains why limited attention has been given to urban governance until recently.

In addition, the particular 'logic' of decentralization that has influenced international trends since the late 1980s has impacted on policy in both Kiribati and Tuvalu (Turner 2003). Most international financial institutions and donors (including those working in the Pacific) have orientated their development assistance on the basis that decentralisation strengthens local democracy, governance and ultimately, development. As small countries reliant on development assistance, this 'supply side' consideration has created an additional incentive for Kiribati and Tuvalu to pursue decentralisation policies.

\section{Central-local relations}

The evolution of stable and cooperative central-local relations is recognised as a building block of successful decentralisation (Turner 2003). The role of central governments is critical in setting the legislative parameters for decentralisation, assisting local governments with financial and technical support, and linking local planning and budgeting with national development priorities. While newly created local governments may initially be reliant on central government grants, the ideal reform outcome is generally seen as one where democratically elected local authorities can generate enough revenue to finance the delivery of services that are responsive to local needs. As this section will elaborate, however, the reform trajectories of Kiribati and Tuvalu have tended to diverge from this ideal type. 
In Tuvalu, the Falekaupule Act (FA) provides for the election of six councillors to each island Kaupule (council), which also has an administrative arm. The Kaupule is in turn accountable in various respects to the island Falekaupule - a body of traditional leaders who hold ultimate decision-making powers over local affairs. The FA also requires Falekaupules to facilitate community participation in local governance processes such as planning and budgeting. The Falekaupule Trust Fund (FTF) was established in 1999 based on contributions from the islands, central government and donors. It is administered independently of central government and is designed to provide greater self-reliance for island communities.

The FTF has provided Tuvalu's local governments with an enviable mechanism for establishing fiscal autonomy from central government. Investment in local governance in Tuvalu averages more than AU $\$ 400$ per capita (Hassall and Tipu 2008). As Hassall and Tipu point out:

per capita expenditure by local government in Tuvalu is higher than in Kiribati,
the closest neighbouring state with a somewhat comparable economic
environment...it could be surmised that Tuvalu's trust fund is contributing
significantly to the wellbeing of communities at the local level. (Hassall and
Tipu 2008: 18-19)

However, the full potential of the FTF has yet to be realised, in part due to unfavourable incentives. Falekaupules and Kaupules have an incentive to direct their requests for funding for specific development projects to national ministries and members of Parliament, rather than the FTF, which is based on their own contributions.

In Kiribati, the legislative basis for decentralisation is the Local Government Act (LGA), which was introduced in 1984 and last amended in 2006. The LGA provides for the devolution of political power to elected island councils, and transfers extensive service delivery responsibilities to the local level, including primary education, public health and provision of utilities. In theory, island councils are fiscally empowered to perform these functions through a combination of recurrent grants from central government and revenues generated locally.

In practice, however, island councils have a small revenue base and little control over service delivery, with the bulk of funding and key staff positions coming from central government ministries (Ortega 2008a). The reluctance of the central government to devolve fiscal and administrative powers appears to be based on both fiscal constraints and concerns about the capacity and competency of island councils to manage local affairs. This catch-22 situation, and the disconnect between legislation and practice, has prevented island councils from maturing into effective institutions for local governance and development. One observer in Kiribati captured the situation by describing the island councils as 'children' who were not yet ready to become independent from their 'parent'. This combination of factors has contributed to a situation where investment in local governance in 
Kiribati is well under AU $\$ 100$ per capita, a low figure even by regional standards (Hassall and Tipu 2008).

The central government, with the support of development partners such as the United Nations Development Programme (UNDP) has sought to address these issues by amending the LGA to increase the terms of island councillors to 4 years, and by intensifying capacity building efforts on the outer islands. It remains to be seen what impact these efforts will have on long term central-local relations and how the significant challenge of financing local governance will be addressed.

This brief overview highlights the challenges of matching finance with function, especially in the context of a limited revenue base and economies of scale. The Falekaupule Trust Fund, while yet to be fully utilised, has provided Tuvalu with an innovative solution that is sustainable and encourages local autonomy in governance and development. Kiribati, with ten times the population of Tuvalu, has yet to identify a mechanism for lifting investment in local governance without heavy reliance on central government grants.

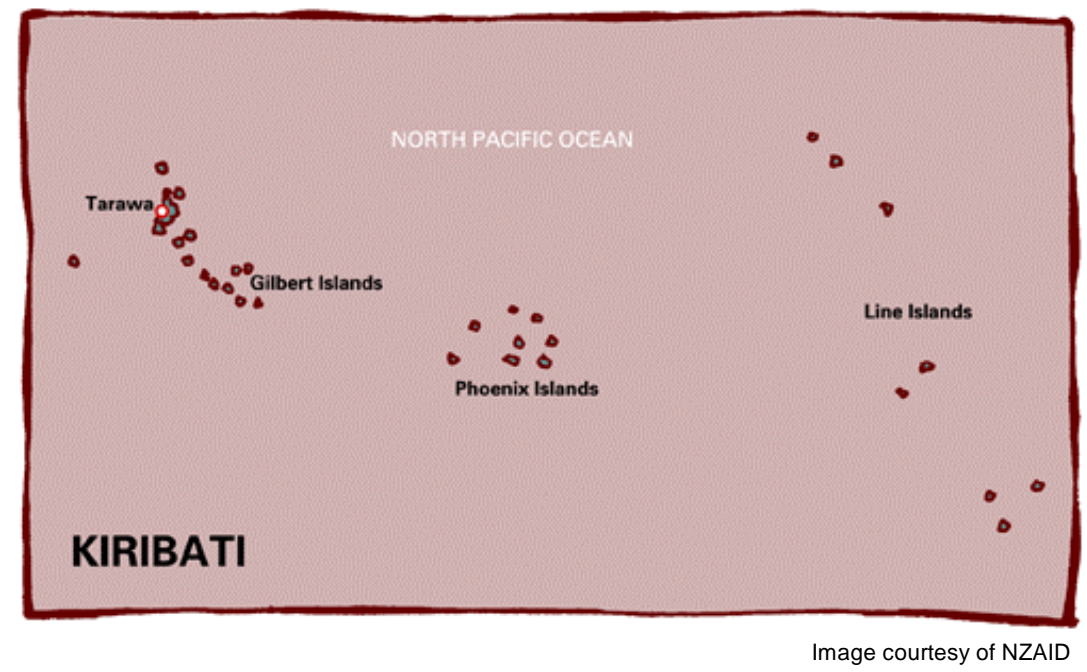

\section{Integration of traditional governance institutions}

The presence of a formal state in local affairs is a relatively new phenomenon in the Pacific (Hassall and Tipu 2008). In many parts of the region, local communities view traditional leaders and mechanisms as the most legitimate and effective institutions for representing their interests and meeting their needs. In most Pacific Island countries, modern local governance institutions were established during or directly after the colonial era, with little regard for how they would integrate with pre-existing institutions. Kiribati and Tuvalu, with their distinctive Micronesian and Polynesian cultures, have both experienced challenges in this area. ${ }^{2}$

2 Tuvalu is Polynesian, retaining features of the chiefly system such as respect for rank, while Kiribati is Melanesian, with greater emphasis on egalitarianism in structuring social affairs. 
In Kiribati's outer islands, the Unimwane, or council of elders, continues to exercise considerable influence despite not being recognised under the Local Government Act. The Unimwane is a key pillar of an egalitarian culture that helps ensure that absolute poverty is virtually unknown in Kiribati (Asian Development Bank 2007). However, Ortega (2008a) describes "long-standing tensions between the traditional leadership and the island councils who are viewed as a central government agency, a tax collector, and a conduit for island development funds" (Ortega 2008a:v). Tensions between the Unimwane and elected island councils also leave little room for participation by marginalised groups such as women and youth. The realities of governance processes at the island level are therefore far more complex and contested than is envisaged under the Local Government Act.

Tuvalu is a rarity in the Pacific, with its traditional and modern governance institutions formally harmonised through the Falekaupule Act. Its success in enabling stronger island autonomy has attracted interest from other countries and experts in the field. However, the contradictions inherent in vesting many local decision-making power in the hands of traditional, unelected leaders are apparent. This is demonstrated by recent events on Nanumaga Island where the Falekaupule, in a variation on traditional sanctions, sacked two Kaupule employees over an issue of religious affiliation (Ortega 2008b). The case highlights the tension between traditional and modern norms and practices, and the caution needed when blending them in formal institutions.

In the case of Tuvalu and Kiribati, traditional leaders and institutions are strongest at the local level and are likely to have an enduring relevance for local governance. The experience of both countries illustrates the need to harmonise the two systems, but the enormous complexities involved mean that the mechanisms for doing so are not easily replicable. Local leaders' dialogues, supported by the Commonwealth Local Government Forum, which bring together traditional and elected leaders, are a useful forum for progressing this agenda. 


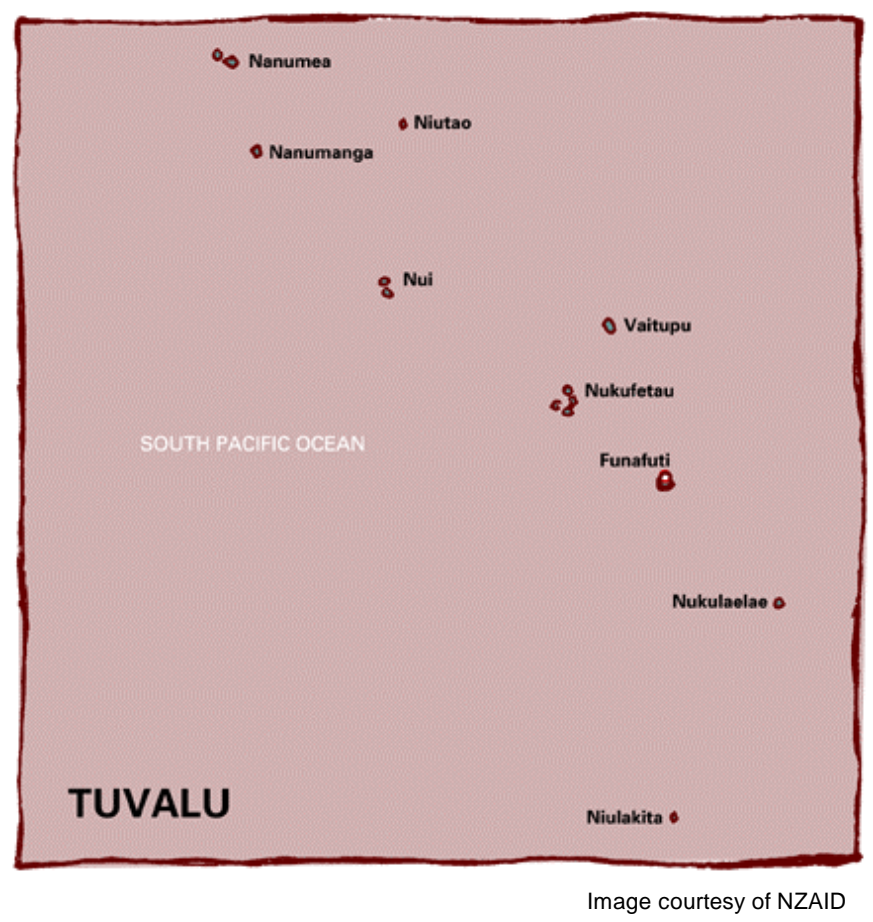

\section{Conclusion}

This brief overview of decentralisation in Kiribati and Tuvalu suggests that there are significant items on the international decentralisation 'menu' that have been inappropriate for both countries. Foremost among these is that full administrative devolution has been unrealistic, as it has been for many other countries in the Pacific region (see Duncan 2004). Responsibilities have not been matched with sufficient finances and this has resulted in poor service delivery and diminished confidence by local communities in the ability of local governments to deliver. As Schoeffel points out: "cutting the pie into smaller pieces doesn't make the pie any bigger" (Schoeffel 2003:4). In the case of Tuvalu, this has been partly resolved by the Falekaupule Trust Fund, but in Kiribati financing remains arguably the biggest constraint to improved local governance.

A second area of divergence is the relationship between traditional and modern governance systems. The lesson from the Kiribati and Tuvalu experience would seem to be that while ignoring traditional institutions and leaders is a recipe for weakening local governance, giving them widespread powers may also be problematic. It is also apparent that the country-specific complexities of this issue make generic international models (which generally focus on modern institutions) less relevant. Having said this, given the similar challenges they face, there is significant potential for Pacific Island countries to learn from each other with regard to the harmonisation of traditional and modern systems.

Kiribati and Tuvalu share common histories and similar natural endowments and development challenges, yet their approaches to outer island governance have been 
markedly different. The institutional, political and cultural factors discussed in this paper appear to have been pivotal in setting the two countries on different paths of decentralisation. Of the two approaches, Tuvalu's has been more successful in financial terms, but it is unclear whether the Tuvalu approach would have been (in the past or present) technically or politically feasible in Kiribati. What is clear is that despite threats such as urbanisation and climate change, economic and political necessity will continue to drive demands for stronger local governance on the outer islands.

\section{Relevant resources}

UNDP Decentralisation and Local Governance practice area $<$ http://www.undp.org/governance/sl-dlgud.htm> and Practice Note <http://www.undp.org/governance/docs/DLGUD_PN_English.pdf>

ADB 2006, Evaluation of the Tuvalu Islands Development Program, <http://www.adb.org/Documents/PPERs/TUV/PPER-TIDP.asp>

NZAID, Tuvalu, <http://www.nzaid.govt.nz/programmes/c-tuvalu.html >

NZAID, Kiribati, <http://www.nzaid.govt.nz/programmes/c-kiribati.html>

\section{Acknowledgements}

The author wishes to thank an anonymous reviewer for helpful suggestions of points for clarification, and of other enhancements to the manuscript. The views expressed in this paper are his own and do not reflect UNDP policy.

\section{References}

Asian Development Bank, 2003. 'Priorities of the People: Hardship in Tuvalu', <http://www.adb.org/Documents/Reports/Priorities_Poor/TUV/default.asp>

Asian Development Bank, 2007. 'Priorities of the People: Hardship in Kiribati', <http://www.adb.org/Documents/Reports/Hardship-Kiribati/default.asp>.

Commonwealth Secretariat, 2005. Local Democracy and Good Governance in the Pacific, Report Number 2, Commonwealth Secretariat, London, UK.

Duncan, R. 2004. 'An Overview of Decentralisation and Local Governance Structures in the Pacific Region', Making Local Governance Work, Suva, Fiji Islands, 4-8 December, 2004, <http://www.usp.ac.fj/fileadmin/files/Institutes/piasdg/governance_papers/duncan_d ecentralisation.pdf $>$.

Government of Kiribati, 2003. 'National Development Strategies 2004 - 2007'. Available at: 〈http://www.forumsec.org.fj>.

Government of Tuvalu, 2004. 'Te Kakeega II: National Strategy for Sustainable Development 2005-2015', <http://www.forumsec.org.fj>.

Hassall, G.; Tipu, F. 2008. 'Local Government in the South Pacific Islands', Commonwealth Journal of Local Governance, Issue 1: May 2008, pp.1-24.

Litvack, J.; Ahmad, J.; Bird, R. 1998. 'Rethinking Decentralisation in Developing Countries'. World Bank Sector Studies Series 21491, 
<http://www1.worldbank.org/publicsector/decentralization/Rethinking\%20Decentral ization.pdf>.

Ortega, M-A. 2008a. 'Strengthening Decentralized Governance in Kiribati Project Evaluation Report', Independent Evaluation of UNDP Project.

Ortega, M-A. 2008. 'Support for Local Governance for Enhanced Island Development in Tuvalu Project - Evaluation Report', Independent Evaluation of UNDP Project.

Schoeffel, P. 2003. 'Local-level Governance in the Pacific', State, Society and Governance in Melanesia, Australian National University. Discussion Paper 2003/7,

<http://rspas.anu.edu.au/papers/melanesia/discussion_papers/schoeffel_turner.pdf $>$.

Turner, M. 2003. 'Issues in the Design of Decentralisation', State, Society and Governance in Melanesia, Australian National University. Discussion Paper 2003/7,

<http://rspas.anu.edu.au/papers/melanesia/discussion_papers/schoeffel_turner.pdf $>$. 